\title{
EVIDENCE FOR THE PENETRATION OF THE VITELLINE MEMBRANE OF THE HEN'S OVUM BY A TRYPSIN-LIKE ACROSOMAL ENZYME
}

\author{
B. HOWARTH, JR AND S. T. DIGBY \\ Department of Poultry Science, University of Georgia, \\ Athens, Georgia 30601, U.S.A. \\ (Received 11th September 1972)
}

In the process of fertilization, most mammalian spermatozoa must penetrate through a series of egg investments before reaching the vitelline membrane. By contrast, cock spermatozoa have only to penetrate the vitelline membrane of the hen's ovum. The composition of the vitelline membrane of the hen's ovum at the time of ovulation has been described by Bellairs, Harkness \& Harkness (1963) as a single layer of connective tissue-like protein.

Sperm penetration of the investments surrounding mammalian ova is aided by hydrolytic enzymes contained within the sperm acrosome. One of these enzymes is a trypsin-like enzyme (TLE) or protease which has been demonstrated by Stambaugh \& Buckley (1969) to be active in the dissolution of the zona pellucida of rabbit ova. Cock spermatozoa have also been shown to contain a high trypsin-like enzymatic activity (Buruiana, 1956; Ho \& Meizel, 1970). More recently, Polakoski (1972) has shown that the high trypsin-like activity is present in the acrosomes (acrosomal extracts) of cock spermatozoa.

Since the avian ovum is surrounded by a vitelline membrane and no other investments at the time of ovulation and fertilization, penetration of the vitelline membrane by a trypsin-like acrosomal enzyme was evaluated using an in-vitro test system. Recently ovulated ova were collected from the infundibulum of White Leghorn hens. Prediction of the time of ovulation was based on knowledge of the time of oviposition. On average, ovulation of the succeeding ovum usually occurs $30 \mathrm{~min}$ after oviposition (Olsen \& Neher, 1948). After their recovery, all ova were placed individually in plastic shells (Pl. 1, Fig. la) and suspended in $15 \mathrm{ml}$ modified Ringer's solution (Olsen \& Nehr, 1948). Recently collected, undiluted pooled semen $(0.05 \mathrm{ml})$ was added to each of fifteen ova (referred to as the untreated control group). Of the fifteen ova, twelve were collected from the infundibulum and three from the magnum. Pooled semen samples were collected by the method of Burrows \& Quinn (1937).

A second group of ten ova (referred to as the treated group) was exposed to $0.05 \mathrm{ml}$ pooled semen incubated with tosyl-L-lysine chloromethyl ketone (TLCK), a synthetic irreversible trypsin inhibitor. The inhibitor was dissolved in modified Ringer's solution at a concentration of $1000 \mu \mathrm{g} / \mathrm{ml}$. Each $0.05 \mathrm{ml}$ semen was incubated for $20 \mathrm{~min}$ at $37^{\circ} \mathrm{C}$ with $0.10 \mathrm{ml}$ TLCK solution ( $100 \mu \mathrm{g}$ TLCK/ $0.05 \mathrm{ml}$ semen). Sperm motility was observed before and after incubation with 
TLCK and at the end of the experimental period. Sperm numbers were deternined using a haemocytometer. Following the addition of semen, all ova were incubated in vitro for $35 \mathrm{~min}$ at $39^{\circ} \mathrm{C}$. Sperm penetration of the vitelline membrane was evaluated by rupture of the membrane which was demonstrated under the conditions of this study.

High levels of synthetic trypsin inhibitors have been shown to kill rabbit spermatozoa (Zaneveld, Robertson \& Williams, 1970). The amounts of TLGK used in the present study had no visible effect on sperm motility. Both TLCKtreated and untreated (control) spermatozoa maintained motility throughout the experimental period. Sperm numbers ranged from 126 to $150 \times 10^{6} / 0.05 \mathrm{ml}$ semen added to ova in the untreated control group. Sperm numbers added to ova in the treated group ranged from 126 to $156 \times 10^{6} / 0.05 \mathrm{ml}$.

In the untreated control group, nine out of twelve ova recovered from the infundibulum ruptured in the region of the germinal disc within $35 \mathrm{~min}$ of the addition of spermatozoa (Pl. 1, Fig. 1b; Table 1). This was not so surprising as it might have been in the case of mammalian ova, since the penetration of the

Table 1. Inhibition of a trypsin-like acrosomal enzyme in cock spermatozoa by TLCK and its effect on sperm penetration in vitro of the vitelline membrane*

\begin{tabular}{c|l|c|c}
\hline $\begin{array}{c}\text { Experimental } \\
\text { group }\end{array}$ & $\begin{array}{c}\text { Sile of ovum } \\
\text { recovery }\end{array}$ & $\begin{array}{c}\text { No. of } \\
\text { ova }\end{array}$ & $\begin{array}{c}\text { No. of ova } \\
\text { ruptured }\end{array}$ \\
\cline { 2 - 3 } & Infundibulum & 12 & 9 \\
Untreated (control) & Magnum & 3 & 0 \\
Treated (TLCK) & Infundibulum & 10 & 0 \\
\hline
\end{tabular}

For abbreviations, see text.

* Sperm penetration of the vitelline membrane was evaluated by rupture of the membrane in the region of the germinal disc.

vitelline membrane by supernumerary spermatozoa is found regularly in birds, including the chicken (Fankhauser \& Moore, 1941; Olsen, 1942). The three ova recovered from the magnum failed to rupture. Using electron microscopy, Bellairs et al. (1963) have shown that in the hen just before ovulation, the vitelline membranes of ovarian ova are composed of a single (inner) layer. By contrast, the vitelline membranes of oviducal ova taken from the magnum possess both an inner and outer layer as well as a continuous membrane and are indistinguishable from membranes surrounding recently laid eggs. Upon chemical analysis, Bellairs et al. (1963) found that the inner and outer layers of the vitelline membrane differ in amino acid composition. Consequently, an alteration in the structural characteristics of the vitelline membranes of the three ova recovered from the magnum could have accounted for the lack of sperm penetration as shown by their failure to rupture.

In contrast to the untreated control group of ova, none of ten ova exposed to TLCK-treated spermatozoa ruptured (Table 1). This would suggest the necessity of an active acrosomal trypsin-like enzyme (TLE) for digestion and penetration of the vitelline membrane of the hen's ovum. In support of this 

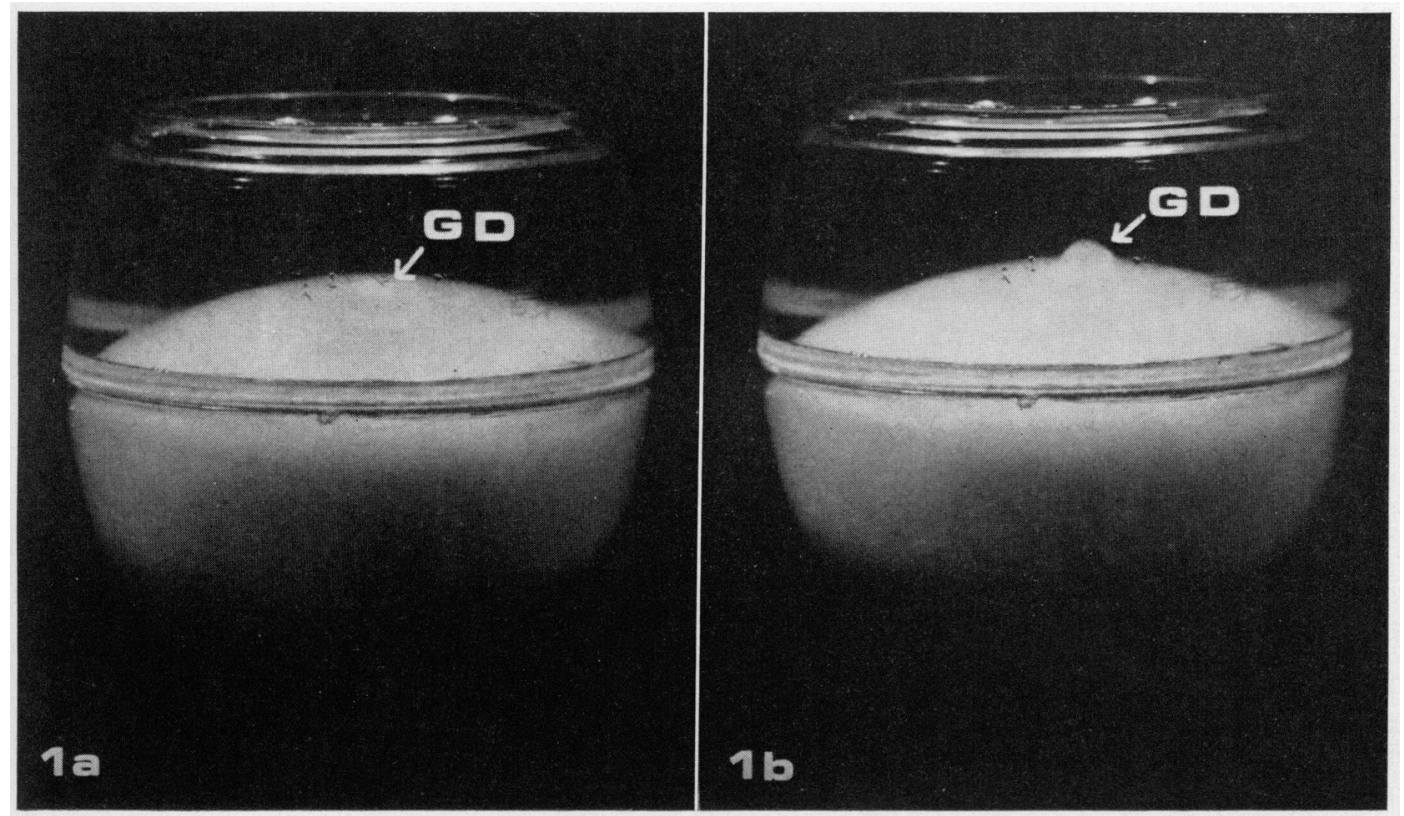

Fisc. 1. (a) Plastic shell used in the in-iitro test system containing a hen's ovum suspended in modified Ringer's solution. 'The photograph shows the location of the germinal dise (al). (b) $\mathrm{H}$ en s orum showing rupture of the vitelline membrane in the germinal dixe (G1) region. 35 min after the addition of untreated (control) spermatoroal. 
hypothesis, observations in this laboratory indicate that the addition of TLCK to cock spermatozoa before insemination effectively reduces fertilization in vivo. These observations on the action of a TLE in cock spermatozoa corresponds with the activity of the TLE of rabbit spermatozoa in the dissolution of the zona pellucida (Stambaugh \& Buckley, 1969). Inhibition of the acrosomal TLE of rabbit spermatozoa has also been shown to be successful in preventing fertilization both in vivo (Zaneveld et al., 1970, Zaneveld, Robertson, Kessler \& Williams, 1971) and in vitro (Stambaugh, Brackett \& Mastroianni, 1969).

The observation that rupture of the vitelline membrane always occurred at the site of the germinal disc suggests the possibility of a chemotactic attraction of spermatozoa to the germinal-disc region where the nucleus of the hen's ovum is located or a different chemical (amino acid) composition of the membrane in this region which might be more susceptible to digestion by a TLE. Considering the relatively small surface area presented by the germinal disc in comparison to the total surface area of the hen's ovum, it is conceivable that a mechanism for ensuring sperm penetration in this region would be advantageous in ensuring syngamy.

The TLCK used in this study was supplied by Dr W. L. Williams, Department of Biochemistry, University of Georgia.

\section{REFERENGES}

Bellairs, R., Harkness, M. \& Harkness, R. D. (1963) The vitelline membrane of the hen's egg: a chemical and electron microscopical study. F. Ultrastruct, Res. 8, 339.

Burrows, W. H. \& Quin, J. P. (1937) Collection of spermatozoa from domestic fowl and turkey. Poult. Sci. 16, 19.

Buruiana, L. M. (1956) Sur l'activité hyaluronidasique et trypsinique du sperme. Naturwissenschaften, 43, 523.

Fankhauser, G. \& Moore, C. (1941) Cytological and experimental studies of polyspermy in the newt, Triturus viridescens. I. Normal fertilization. f. Morph. 68, 347.

Ho, J. J. L. \& Meizes, S. (1970) Electrophoretic detection of multiple forms of trypsin-like activity in spermatozoa of the domestic fowl. 7. Reprod. Fert. 23, 177.

OLSEN, M. W. (1942) Maturation, fertilization and early cleavage in the hen's egg. F. Morph. 70, 513.

Orsen, M. W. \& Neher, B. H. (1948) The site of fertilization in the domestic fowl. F. exp. Zool. 109, 355.

Polakoski, K. L. (1972) Properties and function of enzymes and inhibitors involved in mammalian fertilization. Ph.D. thesis, Department of Biochemistry, University of Georgia.

Stambaugh, R., Brackett, B. G. \& Mastrioanni, L. (1969) Inhibition of in vitro fertilization of rabbit ova by trypsin inhibitors. Biol. Reprod. 1, 223.

Stambaugh, R. \& Buckley, J. (1969) Identification and subcellular localization of the enzymes effecting penetration of the zona pellucida by rabbit spermatozoa. F. Reprod. Fert, 19, 423.

Zaneveld, L. J. D., Robertson, R. T., Kessler, M. \& Williams, W. L. (1971) Inhibition of fertilization in vivo by pancreatic and seminal plasma trypsin inhibitors. F. Reprod. Fert. 25, 387.

Zaneveld, L. J. D., Robertson, R. T. \& Williams, W. L. (1970) Synthetic enzyme inhibitors as antifertility agents. FEBS Lett. 11, 345. 